\title{
British research council seeks to cut role of collective peer review
}

London. A radical change in the way that research grant applications are evaluated for funding, eliminating the role of peer review committees and increasing the discretionary powers of programme managers, is being proposed for Britain's new Engineering and Physical Sciences Research Council (EPSRC).

The move is part of a governmentinspired strategy both to streamline the operation of the research councils, and to sions to the perception of a research project's potential contribution to wealth creation.

At present, all grant applications submitted to the Science and Engineering Research Council (SERC) are assessed by the members of one of the SERC's specialist review committees. The committee members collectively assign a score to each application, and those receiving the highest scores are put forward for funding.

A radical change is now being proposed for the EPSRC, which will take over a large proportion of the responsibilities of the SERC from the beginning of next month, in line with the recommendations of last year's white paper on science. (Most of the SERC's increase the weight given in funding deci-

remaining activities will be taken on by the new Particle Physics and Astronomy Research Council.)

The proposed changes, which have been drawn up by SERC officials, will be put to the new council next month. These suggest that the review committees should be abolished, and that future applications for research grants will be assessed by programme managers, drawing on advice from outside referees.

"Peer review in the way that the SERC used to run it is being changed," a spokesman for the council said on Monday. "We are moving to a managed system, where peer reviewers will still be used as advisers, but will not have the delegated executive authority [to make judgements on applications] that they have at present."

The changes are part of a general shakeup of the way that research councils operate which is being demanded by the Office of Science and Technology, and steered through by John Cadogan, the new directorgeneral of research councils.

Last month, for example, William Waldegrave, the cabinet minister responsible for science, announced that half of an

\section{Deep-sea probe draws up a blank screen}

Tokyo. Japan's new unmanned deep-sea probe Kaiko has run into more bad luck. Last week, Kaiko set out to break the world depth record in the Challenger Deep off Guam. But after it had travelled down to about 10,900 metres, the television pictures it had been transmitting suddenly went blank 2 metres short of the sea floor, and the probe had to be hauled back to its mother ship, Yokosuka.

Kaiko will have to return to Japan for repairs, and a second attempt at breaking the 34-year-old record of 10,912 metres set by the Bathyscaphe Trieste in Challenger Deep in 1960 will have to wait until at least December. Last August, the hull of Kaiko was badly damaged during trials when it slammed into the side of the Yokosuka as it was being lowered into rough seas. The test in the Challenger Deep had to be delayed about seven months as a result of this accident.

The precise reason for last week's failure is unknown, but is believed to have been caused by a fault in the data transmission cable between the probe and the Yokosuka. The Kaiko has a manipulator arm that can be remotely operated to pick up samples spotted by the television cameras, and will therefore be able to perform extra $£ 15$ million which is to be spent on new research programmes designed to further the white paper's objectives is to be found from efficiency savings within the research councils.

The prospect of cutting down on the bureaucracy which currently accompanies the grant review process is likely to be welcomed in the scientific community, many of whose members complain of the amount of time and paperwork they have to spend on current procedures for assessing applications.

At the same time, however, there is concern that the new procedures could undermine the traditional peer review process, and reduce the weight given to scientific quality in comparison to other criteria for assessing research proposals - in particular their explicit industrial relevance.

"Many academic scientists will be unhappy with this change," one SERC committee member said last week. "Despite the amount of work involved, we like the existing system because we feel it does a reasonable job, and doubt whether a different way of doing things will be an improvement."

Some of the supporters of the change point out that giving greater responsibilities to programme managers will bring the EPSRC's system for allocating grants closer to that of other countries, for example the US National Science Foundation (NSF).

But its critics point to the significant difference that, in the United States, most scientists are faced with a range of potential sources of federal support. In contrast, the SERC is the sole source of public funding (apart from that provided through the university funding councils) for university scientists in many fields.

In addition, NSF programme managers tend to be academic scientists working on secondment to the agency. In contrast, the programme managers which the SERC is proposing should now be responsible for handling grant applications will be permanent SERC employees.

"For such a system to work, the programme managers must be individuals who can command respect in the scientific community," says John Mulvey, secretary of the pressure group Save British Science.

SERC officials insist that the new procedures are an integral part of the 'culture change' that will be involved in the council's transformation into its new form, emphasizing the priorities outlined in the white paper and the council's responsibility to meet its new 'missions' of improving wealth creation and the quality of life.

But the proposed changes seem 
destined to generate considerable controversy in the scientific community, coinciding as they do with other indications that a concern for industrially relevant research may overshadow arguments about the need to devise a system for ensuring the maintenance of high scientific standards.

"It is a very dangerous step to take," says Lewis Moonie, the Labour Party's science spokesman. "The peer review system works fairly well, and something that works well should not be changed, while the purpose of the research councils is to fund basic research, not to plug the gaps caused by cutbacks elsewhere in the government's funding of applied research." David Dickson - Richard Brook, Cookson Professor of Materials Science and head of the department of material at Oxford University, has been appointed the first chief executive officer of the new Engineering and Physical Sciences Research Council.

Brook is a specialist in ceramics and their application to mechanical engineering, and is currently chairman of the SERC's materials commission, as well as vice-president of the Institute of Materials.

His appointment completes the government's team of new research councils' heads, each now having an industrialist as a parttime chairman, and an academic scientist as a full-time chief executive officer.

\section{Cancer geneticists sign deal with genome company}

Washington. A collaborative agreement has been signed by a research team led by Bert Vogelstein and Kenneth Kinzler at Johns Hopkins University, Maryland, and the gene sequencing company Human Genome Sciences (HGS).

The deal will give HGS exclusive licensing rights to the outcome of research carried out at Johns Hopkins into the connection between colon cancer and genes sequenced at both HGS and its non-profit associate, Craig Venter's Institute for Genomic Research.

William Haseltine, the chairman of HGS, says the deal is no different from the agreement which any laboratory would use to protect its intellectual property. But he adds that it is the first of many such agreements which HGS hopes to sign.

Vogelstein - the top-cited scientist of 1993, primarily for his work on the genetic basis of cancer, according to statistics compiled by the Philadelphia-based newsletter ScienceWatch in which Kinzler was second — is reluctant to give further details about the deal. He says that its significance will become clearer when research connected with it, which is already completed and has been submitted to a US journal, is published.

c. $\mathbf{M}$.

\section{Fiscal limits cut impact of Clinton's technology dream}

Washington. Al Gore, the US vice-president, last week launched a joint research and development initiative between the federal government and the US semiconductor industry which, he said, would be "of an entirely different order of magnitude" to similar activities already underway.

But the details of the initiative, which will involve the departments of defence, energy and commerce, suggest that it is likely to have a relatively small impact compared to that of the $\$ 4.5$ billion which the US semiconductor industry already spends each year on research.

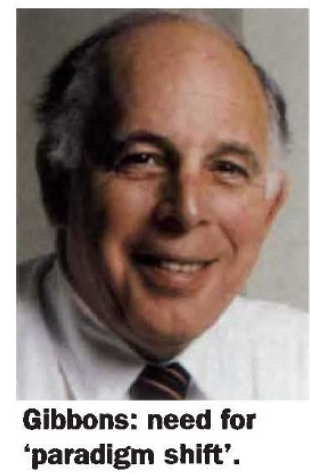

Apart from cre-

ating yet another Washington oversight board - the Semiconductor Technology Council - the initiative will have three substantive elements, one old and two new.

The largest element will come from the Department of Defense, which will continue to invest about $\$ 90$ million a year in Sematech This is a collaboration between government and industry which, despite much criticism, has been running since 1987 , and has lately focused on helping US companies build the machines to make microchips.

This effort will now be complemented by the Department of Energy (DOE), which will spend around $\$ 50$ million over the next five years on a centre to help the microchip industry with computer simulation. The Department of Commerce will provide up to $£ 25$ million over this period through the National Institute of Standards and Technology (NIST) for a metrology centre to help the industry measure tiny distances. In each case, industry is expected to match the government's investment.

The new initiative has been generally welcomed by the electronics industry. But, as the US government slowly begins to steer its $\$ 72$ billion research budget away from fundamental science towards applied research, the key question remains whether initiatives of this type will actually produce significant economic benefits.

Last week, top managers from the industry who had gathered in Washington to help launch the new initiative praised Sematech's track record, and dutifully pledged that the advantages promised by Gore from the additional efforts will be forthcoming.

Craig Barrett, chief executive of Intel and president of the Semiconductor Indus- try Association, said Sematech had helped his industry "to pull itself together" in the face of the Japanese threat in the late 1980s. He added that the new deal would prove "as vital an influence as Sematech was over the last five years."

But few view Sematech as pivotal in the turnaround achieved by the US industry, which last year overtook Japan as market leaders for the first time since 1985. Sematech itself encountered problems early in its life, and some members pulled out as its original goal of getting rival firms to co-operate on chip development proved unrealistic.

The collaboration has since become more narrowly defined, concentrating on semiconductor manufacturing equipment, and is widely credited in the industry with improving the quality of such equipment built in the United States.

But if the administration really wanted to expand the Sematech model into a substantial inter-agency partnership, fiscal constraints seem to have prevented it from doing so. In practice, the amount of new money is trivial compared with the overall research and development budgets of the industry.

Despite funding restrictions, administration officials claim the new initiative will still have a significant impact. "We want to strengthen a partnership which has already become profound," Jack Gibbons, the president's science advisor, said last week.

Gibbons says that the semiconductor industry "is facing challenges which may call for a paradigm shift". As chips get smaller, he adds, "engineers will have to know quantum mechanics that were previously only of interest to physicists".

Energy secretary Hazel O'Leary said that the initiative differed from previous policy both in its multi-agency nature, and in the spirit in which it was entered into. "In the past five years it was a reluctant partnership," she said. "We are attesting to the fact that we like this partnership, and we need others like it." Although O'Leary talked of selecting a site for the DoE computer simulation centre, officials said the money was likely to be divided between the department's Sandia, Los Alamos and Lawrence Livermore laboratories.

The administration's hope is that the centres to be set up by NIST and the DoE will successfully focus on small niches which the industry might otherwise neglect.

Furthermore, the semiconductor industry may be feeling that, however hollow the idea of a 'research partnership' with government, a public expression of gratitude is a small price to pay for favours it has received elsewhere, for example in trade negotiations with the Japanese.

Colin Macilwain 